\title{
ANATOMIC STUDY OF PORTAL VEIN. TRANSPANCREATIC VESSELS INJURIES APPROACH ${ }^{1}$
}

\author{
Mario Mantovani \\ Raquel Franco Leal ${ }^{3}$ \\ Mauro José Fontelles ${ }^{4}$
}

\begin{abstract}
Mantovani M, Leal RF, Fontelles MJ. Anatomic study of portal vein: transpancreatic vessels injuries approach. Acta Cir Bras [serial online] 2002 Jul-Aug;17(4). Available from URL: http://www.scielo.br/acb.
\end{abstract}

\begin{abstract}
Introduction: The commitment of the great blood-vessels make up a situation of great complexity and a high rate of the complications and mortality patients with abdominal trauma. The injury of the portal vein matters because of the difficulty on the diagnosis and the approach surgery. Objective: To set the standard on the transverse section of the pancreas looking for a safer surgical access to repair the portal vein injuries. Methods: A quantitative analysis was performed to characterize the anatomical relationship between the portal vein and their tributaries relating them to the pancreas. On these corpses, the measurements of a anatomical triangle were studied. It base was the upper limit of the superior mesenteric vein and the initial portion of the portal vein; the apex, a point located on the upper limit of the confluence of the splenic vein and superior mesenteric vein, situated at the middle line of the superior mesenteric vein. Results: The portal vein is formed $3.24 \mathrm{~cm}$ from the internal border of the duodenal arc at a distance of $1.61 \mathrm{~cm}$ and 1.07 from the inferior and superior pancreas borders, respectively. Conclusion: The present study allow us to conclude that, to have access to the origin of the portal vein, in case of trauma of this vessel, one should proceed a transverse section of the neck of the pancreas next to the superior mesenteric vein, because its confluence with splenic vein occur, on average, $1.07 \mathrm{~cm}$ and $1.61 \mathrm{~cm}$ from the superior and inferior border of the gland, respectively.
\end{abstract}

KEY WORDS - Abdominal injuries. Portal vein. Hepatic veins. Pancreas.

\section{INTRODUCTION}

In the trauma, the simultaneous commitment of intraabdominal structures, as the large vessels and adjacent organs, is referred in the literature as a situation of great complexity, almost always associated with severe complications and high postoperative mortality rates, becoming, technically, a challenge to surgeon. Among them, the injuries of the large vessels, present on $5 \%$ to $25 \%$ of patients admitted to hospitals with abdominal trauma, is the most common cause of death. On these patients, is extremely important the occurrence of injuries to the anatomical structures of the portal triad, an uncommon condition, but with great lethality because difficult to diagnosis and uncontrolled intraabdominal hemorrhage that they are subjected during the surgical treatment $\mathrm{t}^{1,2,3,4}$.

1. This study has been conducted by the Trauma Surgery Division of the Department of Surgery, Faculty of Medical Sciences, UNICAMP - Campinas, S.P.

2. Titular Professor, Chief - Trauma Surgery, Department of Surgery, Faculty of Medical Sciences, UNICAMP.

3. Resident in Surgery of Unicamp Clinical Hospital.

4. Doctor of Trauma Surgery. Professor of Human Anatomy, Universidade da Amazônia - UNAMA. 
Traumatic injury of the portal vein represents the third greatest cause of death among all abdominal cavity related injuries, surpassed only by abdominal aorta (proximal to the renals) and retrohepatic vena cava injuries with commitment of suprahepatic veins, and the identifying and a rapid control of bleeding sites and urgent correction of hypothermia is a priority on the treatment, a generally complicated procedure by the difficult on to access to the injured vessel ${ }^{4,5,6,7}$. In addition, the trauma of these retropancreatic vessels, frequently, is associated with complete rupture of the pancreas, requiring left pancreatic resection, increasing the occurrence of complications $s^{2,8,9,10}$.

Thus, the objective of the present study was, with utilization of measurements made in corpse, to standard the transverse section of the pancreas aiming a safer surgical access to approach and repairs the portal vein injuries.

\section{METHODS}

In this study, a quantitative analysis was performed so that the anatomical relation of the portal vein and their tributaries could be characterized, that first of all, had their measurement in question standardized in previously preserved corpses (formaldehyde), comprising the initial pilot project. To execute the proposed measures, 30 adult's fresh corpses were used, and submitted to autopsy. It was excluded those with anatomical alterations determined by neoplasm of the pancreas, by a portal hypertension and previous surgery on the studied region.

In all cases studied, we approached the pancreatic region located behind of the_omentum space (Figure 1) and complete transverse section of the neck of the pancreas was performed.

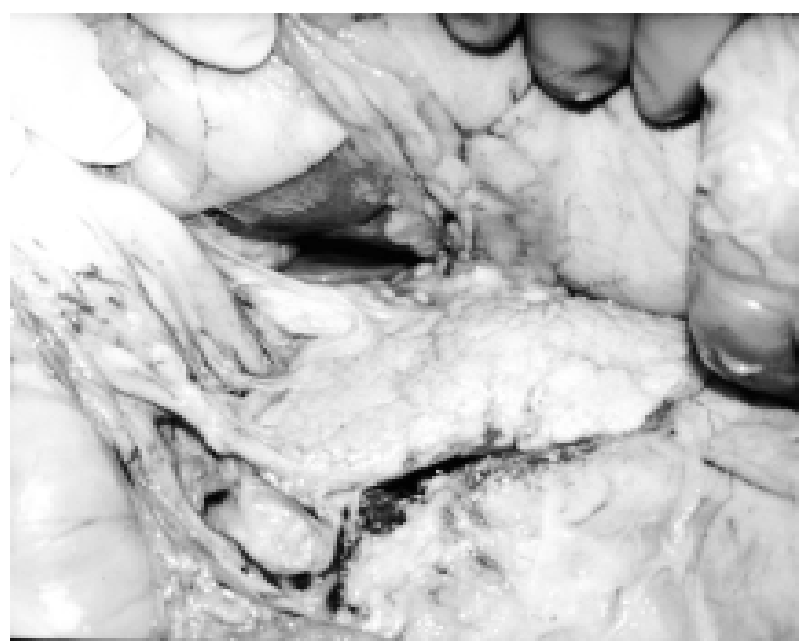

Figure 1 - Pancreas location at the omental cavity.
This maneuver was done on the researcher's index finger, which was introduced behind to the neck of the gland, from the root of mesentery to the portal triad, as a way to orientate the cut of the pancreas (Figure 2) and protect the adjacent anatomical structures (Figure 3).

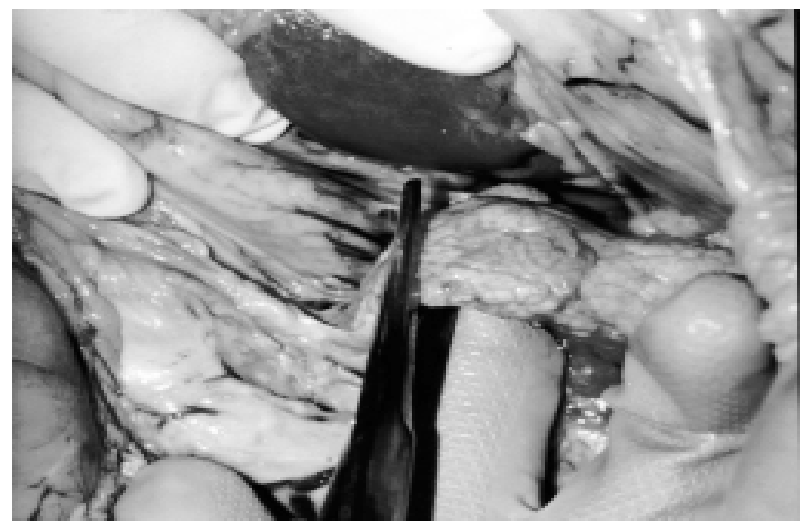

Figure 2 - Cutting of the pancreas and access to the retropancreatics vessels.

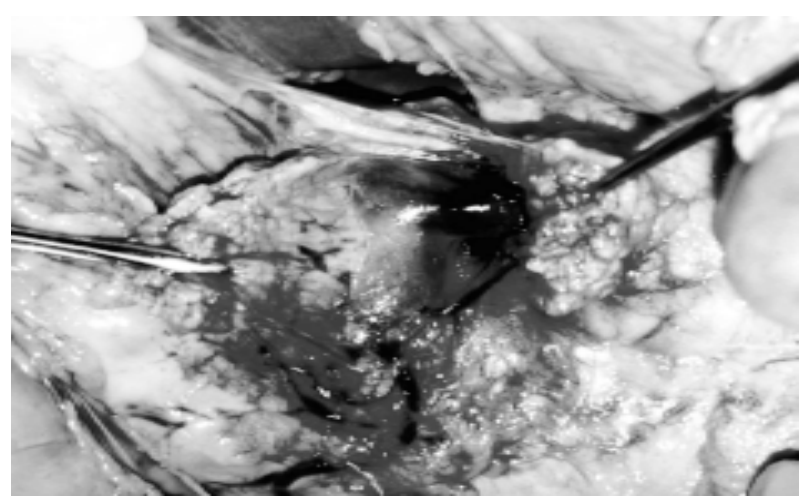

Figure 3 - Retropancreatics vessels expoure. (A - Superior mesenteric veins; B - Splenic vein; C - Hepatic portal vein; D Pancreas).

On these corpses were studied the measures of a anatomical triangle, previously standardized, that has its base in the upper limit of the superior mesenteric vein and the initial part of the portal vein; as apex, a point that is located on the superior limit of the confluence of the splenic and superior mesenteric veins, situated at the middle line of the superior mesenteric vein.

The proposed distances were calculated, in centimeters, using rectangles with dimensions of $1.0 \mathrm{~cm}$ $x 6.0 \mathrm{~cm}$, on card paper, duly staggered. Next, while in the autopsy room, the distances marked on the rectangles were measures, twice each (measurements ' $a$ ' and ' $b$ '), and registered with age, sex and corpse stature (Figure 4). 


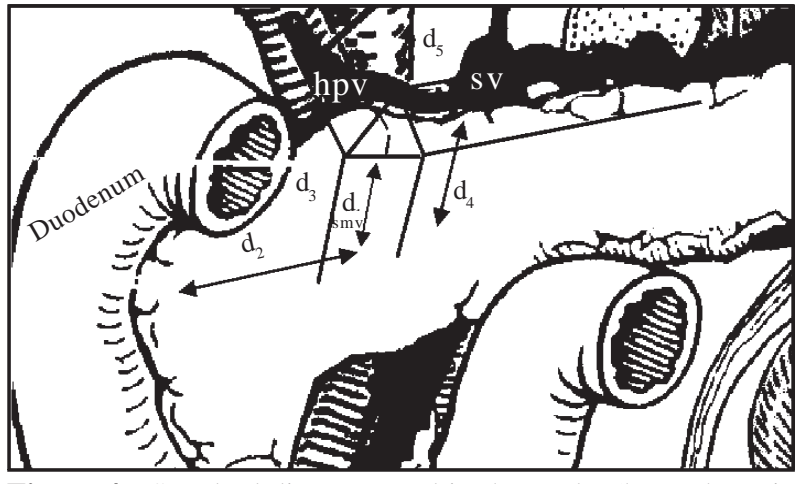

Figure 4 - Standard distance used in the study. (hpv - hepatic portal vein; smv - superior mesenteric vein; sv - splenic vein).

The following distances were standardized:

1) Distance $\mathrm{d} 1$ - From the inferior border of the pancreas to the triangle base, following the middle line of the superior mesenteric vein;

2) Distance d2 - From the superior mesenteric vein to the right limit of the head of the pancreas, on a straight that follows the inferior border of the gland;

3) Distance d3 - Determined by the straight that passes parallel $1.0 \mathrm{~cm}$ to the right of the middle line of the superior mesenteric vein, beginning at the middle line of the portal vein and ending at the inferior border of the pancreas;

4) Distance $\mathrm{d} 4$ - Determined by the straight that passes parallel $1.0 \mathrm{~cm}$ to the left of the middle line of the superior mesenteric vein, beginning at the middle line of the splenic vein and ending at the inferior border of the pancreas;

5) Distance d5 - From the apex of the triangle to the superior border of the pancreas, on a straight that follows the middle line of the superior mesenteric vein;

6) Distance d6 - Corresponds to the width of the pancreas in a projection of the middle line of the superior mesenteric vein;

7) Distance d7 - Corresponds to the semi-circumference of the portal vein, measured at it roots.

With the results, a data bank was developed using the Excel software (Microsoft Co. USA), for personal computer where all the information were registered allowing the statistical analysis. On the comparison analysis between the ' $a$ ' and ' $b$ ' measurements, 2-tailed student test was performed with differences considered significant at $\mathrm{p}<0.05)$. On the comparison analysis of the measurement ' $D$ ' values, the Pearson's coefficient $(\boldsymbol{r}$ value $)$ was used, calculating the determination coefficient $\left(\boldsymbol{r}^{2}\right.$ value $)$ for to test the association force among them, in order to ascertain what was the measure proportion that can be explained by other associate measure. The values of ' $\mathrm{p}$ ' and $\boldsymbol{r}^{2}$ were calculated by the Primer statistical software - version 1.0 (McGraw Hill Libri Italy, 1988).

\section{RESULTS}

In this research, the student test was done between ' $a$ ' and ' $b$ ' value, on all the previously standardized measure showed that they did not differ between them, so it made possible to consider the mean arithmetical measures ' $\mathrm{D}$ ' in all of the measured distances. The table1 shows the values of the measures found on this study.

The follow results were obtained:

a) The portal vein is formed, in average, $1.61 \mathrm{~cm}$ to the inferior border of the pancreas $\left(D_{1}\right)$, and located, in average, $3.24 \mathrm{~cm}$ of the inner border of duodenal $\operatorname{arc}\left(\mathrm{D}_{2}\right)$;

b) The portal vein, measured $1.0 \mathrm{~cm}$ to the right of the middle line, that passes by the superior mesenteric vein, is located, in average, $9.16 \mathrm{~cm}$ $\left(D_{3}\right)$ from the inferior border of the pancreas;

c) The splenic vein, measured $1.0 \mathrm{~cm}$ to the left of the middle line, that passes through the superior mesenteric vein, is located, in average, $1.76 \mathrm{~cm}$ $\left(D_{4}\right)$ from the inferior border of the pancreas;

d) The confluence of the retropancreatic vein occurs, in average, $1.07 \mathrm{~cm}\left(\mathrm{D}_{5}\right)$ from the border of the pancreas, located on straight that passes through the superior mesenteric vein;

e) The width of the neck of the pancreas $\left(\mathrm{D}_{6}\right)$ measures $3.74 \mathrm{~cm}$, in average, and the semi-circumference of the portal vein $\left(D_{7}\right)$ is 1.53 , in average;

f) The distance $D_{6}$ was greater than $D_{3}$ in $73 \%$ of cases.

Beside, that the matrix of correlation (Table 2) showed a positive association between the distances $\mathrm{D}_{1}$ and $\mathrm{D}_{3}\left(\boldsymbol{r}^{2}=59.06 \% ; \mathrm{p}<0.0001\right), \mathrm{D}_{1}$ and $\mathrm{D}_{4}$ $\left(r^{2}=55.63 \% ; \mathrm{p}<0.0001\right)$ and $\mathrm{D}_{3}$ and $\mathrm{D}_{4}\left(r^{2}=44.48 \%\right.$; $\mathrm{p}<0.0001)$. A positive association also took place between $\mathrm{D}_{7}$ (portal vein semi-circumference) and the statures $\left(r^{2}=44.48 \% ; \mathrm{p}=0.013\right)$. There was no positive association between sex or age and considered distances. Neither between distances $\mathrm{D}_{2}$ and the distances that locate the retropancreatics vessels.

\section{DISCUSSION}

On the literature, around $3 \%$ to $12 \%$ of all abdominal traumas include injury to the pancreas, with $2 / 3$ of the cases coming from penetrating injury. On 
Table 1 - Measures obtained according to the studied case.

\begin{tabular}{|c|c|c|c|c|c|c|c|c|c|c|}
\hline \multicolumn{4}{|c|}{ Variables } & \multicolumn{7}{|c|}{$\begin{array}{c}\text { Values 'D' }=\text { average values 'a' }+ \text { 'b' } \\
(\mathrm{cm})\end{array}$} \\
\hline $\begin{array}{c}\text { Case } \\
\text { Number }\end{array}$ & Sex & $\begin{array}{l}\text { Age } \\
\text { (yrs) }\end{array}$ & $\begin{array}{c}\text { Estature } \\
(\mathbf{m})\end{array}$ & $\mathbf{D}_{1}$ & $\mathrm{D}_{2}$ & $\mathbf{D}_{3}$ & $\mathrm{D}_{4}$ & $D_{5}$ & $D_{6}$ & $\mathbf{D}_{7}$ \\
\hline 01 & M & 65 & 1.62 & 3.25 & 2.20 & 4.50 & 2.15 & 1.00 & 4.65 & - \\
\hline 02 & $\mathbf{M}$ & 64 & 1.63 & 1.75 & 3.25 & 3.45 & 2.00 & 0.70 & 3.15 & - \\
\hline 03 & M & 65 & 1.75 & 2.40 & 5.40 & 4.35 & 2.65 & 0.40 & 5.75 & - \\
\hline 04 & M & 69 & 1.62 & 1.95 & 2.45 & 3.90 & 2.50 & 1.20 & 4.65 & - \\
\hline 05 & $\mathbf{M}$ & 24 & 1.60 & 1.20 & 3.25 & 3.40 & 1.20 & 1.10 & 3.05 & - \\
\hline 06 & $\mathbf{M}$ & 84 & 1.70 & 2.75 & 3.30 & 5.30 & 2.40 & 0.78 & 3.00 & - \\
\hline 07 & $\mathbf{M}$ & 50 & 1.66 & 1.28 & 2.90 & 3.75 & 1.48 & 0.70 & 3.05 & - \\
\hline 08 & $\mathbf{F}$ & 74 & 1.50 & 1.20 & 4.25 & 2.95 & 1.35 & 0.60 & 3.35 & - \\
\hline 09 & $\mathbf{M}$ & 49 & 1.80 & 1.40 & 4.70 & 3.20 & 1.05 & 1.40 & 4.40 & - \\
\hline 10 & $\mathbf{F}$ & 45 & 1.55 & 1.50 & 2.40 & 3.25 & 1.60 & 1.35 & 1.45 & - \\
\hline 11 & $\mathbf{F}$ & 23 & 1.54 & 1.65 & 2.05 & 3.30 & 1.80 & 0.90 & 3.20 & - \\
\hline 12 & $\mathbf{F}$ & 30 & 1.60 & 1.80 & 2.05 & 3.50 & 2.15 & 1.55 & 3.70 & 1.45 \\
\hline 13 & M & 42 & 1.74 & 1.90 & 3.25 & 3.35 & 1.75 & 1.20 & 4.60 & 2.55 \\
\hline 14 & $\mathbf{M}$ & 55 & 1.60 & 1.55 & 5.20 & 2.60 & 2.00 & 0.95 & 3.55 & 1.45 \\
\hline 15 & $\mathbf{M}$ & 45 & 1.65 & 1.40 & 4.40 & 3.55 & 2.00 & 0.95 & 3.55 & 1.60 \\
\hline 16 & M & 33 & 1.67 & 1.65 & 4.60 & 3.30 & 2.25 & 1.30 & 3.65 & 1.50 \\
\hline 17 & M & 25 & 1.63 & 1.88 & 4.25 & 3.08 & 1.80 & 1.75 & 3.50 & 1.40 \\
\hline 18 & M & 50 & 1.54 & 1.15 & 2.70 & 2.30 & 1.20 & 1.40 & 5.60 & 1.10 \\
\hline 19 & M & 29 & 1.66 & 1.05 & 1.95 & 2.00 & 0.98 & 1.55 & 2.65 & 2.15 \\
\hline 20 & $\mathbf{F}$ & 31 & 1.64 & 1.05 & 3.30 & 2.85 & 1.35 & 1.90 & 3.40 & 1.65 \\
\hline 21 & M & 45 & 1.62 & 1.10 & 2.15 & 1.85 & 1.30 & 0.65 & 3.05 & 0.65 \\
\hline 22 & M & 38 & 1.68 & 0.85 & 2.60 & 2.55 & 1.00 & 1.20 & 3.90 & 1.35 \\
\hline 23 & $\mathbf{F}$ & 70 & 1.50 & 1.75 & 3.00 & 2.90 & 2.45 & 1.15 & 2.85 & 1.45 \\
\hline 24 & M & 48 & 1.70 & 1.40 & 2.95 & 2.70 & 1.35 & 0.10 & 4.05 & 1.90 \\
\hline 25 & M & 65 & 1.57 & 2.13 & 2.95 & 3.45 & 2.45 & 0.90 & 3.50 & 1.55 \\
\hline 26 & $\mathbf{M}$ & 63 & 1.66 & 1.65 & 2.80 & 4.20 & 2.30 & 1.50 & 3.40 & 2.00 \\
\hline 27 & $\mathbf{F}$ & 65 & 1.65 & 1.40 & 3.78 & 2.45 & 1.95 & 0.58 & 3.23 & 1.20 \\
\hline 28 & M & 65 & 1.77 & 1.70 & 3.40 & 3.30 & 1.75 & 1.00 & 3.40 & 1.75 \\
\hline 29 & $\mathbf{F}$ & 51 & 1.55 & 1.03 & 2.58 & 2.30 & 1.10 & 1.40 & 5.45 & 1.05 \\
\hline 30 & $\mathbf{F}$ & 49 & 1.65 & 1.53 & 3.08 & 2.13 & 1.40 & 0.93 & 5.55 & 1.35 \\
\hline Average & - & 50.4 & 1.64 & 1.61 & 3.24 & 3.16 & 1.76 & 1.07 & 3.74 & 1.53 \\
\hline SD & - & - & - & 0.52 & 0.95 & 0.79 & 0.51 & 0.40 & 0.97 & 0.42 \\
\hline Max. & - & 84 & 1.80 & 3.25 & 5.40 & 5.30 & 2.65 & 1.90 & 5.75 & 2.55 \\
\hline Min. & - & 32 & 1.50 & 0.85 & 1.95 & 1.85 & 0.98 & 0.10 & 1.45 & 0.65 \\
\hline
\end{tabular}

Table 2 - Coefficient of determination value (Value $\mathrm{r}^{2}$ ) according to the association of the variables (distance) studied.

\begin{tabular}{|c|c|c|c|c|c|c|c|c|}
\hline & Age & Stature & $\mathbf{D}_{\mathbf{1}}$ & $\mathbf{D}_{\mathbf{2}}$ & $\mathbf{D}_{\mathbf{3}}$ & $\mathbf{D}_{\mathbf{4}}$ & $\mathbf{D}_{\mathbf{5}}$ & $\mathbf{D}_{\mathbf{6}}$ \\
\hline Age & & & & & & & & \\
\hline Stature & 0.0003 & & & & & & & \\
\hline $\mathbf{D}_{1}$ & 0.2128 & 0.0259 & & & & & & \\
\hline $\mathbf{D}_{2}$ & 0.0292 & 0.1186 & 0.006 & & & & & \\
\hline $\mathbf{D}_{3}$ & 0.1614 & 0.0634 & $\mathbf{0 . 5 9 0 6}$ & 0.0194 & & & & \\
\hline $\mathbf{D}_{4}$ & 0.2330 & 0.00009 & $\mathbf{0 . 5 5 6 3}$ & 0.0487 & $\mathbf{0 . 4 4 4 8}$ & & & \\
\hline $\mathbf{D}_{\mathbf{5}}$ & 0.2205 & 0.0112 & 0.0343 & 0.0341 & 0.0128 & 0.03 & & \\
\hline $\mathbf{D}_{6}$ & 0.0139 & 0.0465 & 0.0231 & 0.0312 & 0.0014 & 0.0001 & 0.0027 & \\
\hline $\mathbf{D}_{7}$ & 0.0089 & $\mathbf{0 . 3 0 8 8}$ & 0.1162 & 0.0016 & 0.2408 & 0.0225 & 0.0179 & 0.0251 \\
\hline
\end{tabular}


this type of trauma the mortality varies from $10 \%$ to $30 \%$ on the most complicated ones, occurring in most part during the first 48 hours after the traumatic event, due to the hemorrhagic shock effects associated to the injury of the adjacent vascular structures. Approximately $1 / 3$ of the patients that survive the initial trauma, will show, during the recovery period, complications due to injuries of their own guts, like fistulae, pancreatic dysfunction, pseudocyst or abscesses, each one with less than $10 \%$ of mortality ${ }^{11,12,13}$.

The pancreas, a mixed, soft, lobulated, retroperitoneal gland, with very irregular form, annexed to the duodenum, has, anatomically, a head, neck, body and tail. Its dimension varies from $16 \mathrm{~cm}$ to $20 \mathrm{~cm}$, lengthwise; $4.0 \mathrm{~cm}$ to $5.0 \mathrm{~cm}$ of height and $2.0 \mathrm{~cm}$ to $4.0 \mathrm{~cm}$ of thickness, weighting about 70 grams. Located in the epigastrium and left hipocondrium, lies in a transversal position. Behind the stomach, crossing the spinal cord at the vertebrate body level L1 and L3. The posterior face relates with the lower cava vein, abdominal aorta artery and upper mesenteric vein. The artery and splenic vein, mostly frequently, touch the upper gland's brim, and less frequently lie behind the $\operatorname{organ}^{14,15,16}$. The neck is also related to two important arteries; above, the celiac trunk, and below, the superior mesenteric artery.

The posterior face of the isthmus (or pancreas neck), that has width of $3.0 \mathrm{~cm}$ to $4.0 \mathrm{~cm}$, and extension of $1.5 \mathrm{~cm}$ to $2.0 \mathrm{~cm}$, it is involved by a deep depression of vertical orientation and light oblique to the left, where segments of superior mesenteric vein and hepatic portal vein are found. In this region, in $85 \%$ of the cases the hepatic portal vein is found, on $15 \%$ of the individuals the inferior mesenteric vein is part of his formation ${ }^{16,17}$. The hepatic portal vein is responsible for the venous drainage of the abdominal gut area, what corresponds to the $27 \%$ of cardiac debit flow, and $75 \%$ of the hepatic blood volume. From the anatomical point of view, lies on the gastroduodenal ligament, afterwards to the hepatic artery and to the choledochus, presenting a length of $8.0 \mathrm{~cm}$ to $10.0 \mathrm{~cm}$, and caliber that varies from $8.0 \mathrm{~cm}$ to $10.0 \mathrm{~cm}$, which justify the severe trauma on them ${ }^{15,18}$.

In this manner, some anatomo-physiological characteristics of the hepatic portal vein must be remembered. It is a vessel without valves and practically short of elastic fibers, been made of longitudinal muscle fibers and arcuolated tissue. The tributaries that split the head of the pancreas get in by the postero lateral surface, creating area without vessels on its front face, at pancreas' head level, it being free of dissections $^{18}$. It is important to note that, at this point, a cut of the organ is done at the right pancreatic resection, avoiding the vascular injury.
On the other hand, the portal transpancreatic access (whipple maneuver) ${ }^{19}$, used in cases of trauma in the retropancreatic portion of the hepatic portal vein or proximal portion of the superior mesenteric vein superior, must be considered, since trauma of the hepatic portal vein seems to be very unusual, but associated to a high rate of mortality that varies between $54 \%$ and $71 \%$ of the described cases in the literature, what shows the reason of the anatomical study of this vein and its tributaries in relation to the cut's plan done at the time of the surgical access to the vessel ${ }^{2,4,7,9,14,20}$.

To do this procedure, after ample laparotomy, the Kocher maneuver, that consists of the displacement of the duodenum and of the pancreas' head from their posterior insertions, with visualization of the cava vein and retropancreatic structures. Then it is followed by the desinsertion of the colon, including the displacement of the transverse mesocolon of the pancreas' head, to expose of the mesenteric superior vessels. Direction was done in its inferior portion and superior in projection of mesenteric vessels and portal vein, followed by digital retropancreatic exploration to verify the extension of these vessels, and to complete dissection and exploration of the hepatic portal vein, removing it from the pancreas. Next, cutting of this gland, and dissection of it proximal portion with ligation of the vessels and approach under a direct view of the hepatic portal vein.

Once the pancreatic transection is done, proceed to the distal pancreatectomy with ligation of the pancreatic duct apart and stitching of the proximal extremity of the gland ${ }^{21}$ (Figure 5).

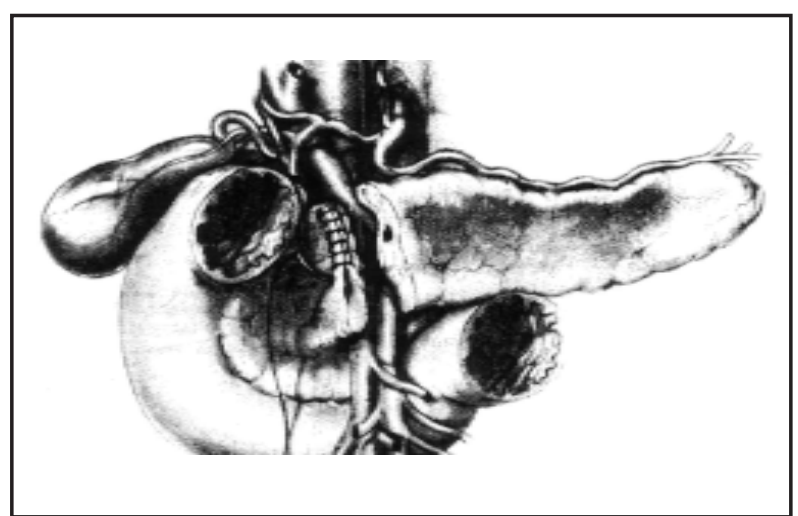

Figure 5 - Surgical repair of the pancreas with non absorbable suture.

This way, after the initial bleeding control is done with manual compression, mobilization of the common bile duct to the left and the cystic duct to the right must be done, complemented with Kocher maneuver, what usually allow the visualization of the suprapancreatic structures. The right kidney and the suprarenal gland must not be mobilized in this 
maneuver ${ }^{3,20,22,23}$. However, to the visualization of the perforation at the retropancreatic portion of the hepatic portal vein or trauma at the proximal portion of the superior mesenteric vein, is necessary the transsection of the pancreas after vascular control of the vein mesenteric superior under the gland and of the hepatoduodenal ligament, above. Here, the surgeon must approach the gastroduodenal artery that will be previously tied. At the same time, this transection must be preceded by the maneuver of introduction of the surgeon's index finger behind to neck of the gland, directing it from the mesenteric root toward the triad portal until it touches the pancreas's head, so it can direct the placement of the two hemostatic tweezes that will serve as support to the incision and splitting of the gland, allowing, as superior mesenteric vein and hepatic portal vein to be visualized in its retropancreatic portions. The surgeon now has less difficulty to repair these important intraabdominal vessels ${ }^{21}$.

Near the cutting place of the pancreas, the reference points used in this work take as bases the placement of the superior mesenteric vein and the neck of the gland, which must be cut in front of the refereed artery. It's important to know that it's no rare for these structures to be hard to identify, especially when the occurrence of pancreatic trauma with active bleeding and big retroperitoneal hematomas is present. In this situation, the distance between the right limit of the pancreas (inner brim of the duodenal arc) and the superior mesenteric vein are taken into consideration, on average, it is $3.24 \pm 0.95 \mathrm{~cm}$ (Distance D4), in this work it changes from $1.95 \mathrm{~cm}$ to $5.40 \mathrm{~cm}$. Furthermore, it is important to remember the fact that the hepatic portal vein remains retropancreatic, at least $1.0 \mathrm{~cm}$ to the right of its formation, on $73 \%$ of the studied cases, hence needing to dissect behind the pancreas head. The observance of these parameters allows the surgeon an easier access and a secure approach to repair the injuries of these vessels.

In the same manner, a positive correlation between the stature and the measurement of the hepatic portal vein' circumference was found, that according to Testut at al. ${ }^{16}$, has a diameter of about $0.8 \mathrm{~cm}$ to $1.0 \mathrm{~cm}$, and a semi-circumference of $1.26 \mathrm{~cm}$ to $1.57 \mathrm{~cm}$. On the present study, the average measurement was $1.53 \mathrm{~cm}$, it been directly proportional to the corpse's stature.

\section{CONCLUSION}

The present study allow us to conclude that in case of trauma, to have access to the origin of the hepatic portal vein, a cutting of the pancreas' neck next to superior mesenteric vein must be proceeded, for the confluence between it and the splenic vein, usually, takes place, in average, $3.2 \mathrm{~cm}$ to the left of the duodenal arc and, $1.07 \mathrm{~cm}$ and $1,61 \mathrm{~cm}$ of the upper ad inferior border of the gland, respectively.

\section{ACKNOWLEDGMENT}

Our thanks to Mr. Edilson Silva Junior for the help on the translation of the present paper.

\section{REFERENCES}

1. Aleksandrovich GL, Rudenko II. Injury of majors blood vessels in abdominal trauma. Khirurgiia (Mosk) 1991; 12:66-9.

2. Dawson DL, Johansen KH, Jurkovich GJ. Injuries to the portal triad. Am J Surg 1991; 161(5):545-51.

3. Jurkovich GJ, Hoyt DB, Moore FA, Ney AL, Morris JA, Scalea TM, Patcher HL, Davis JW. Portal triad injuries. J Trauma 1995; 39(3):426-34.

4. Tyburski JG, Wilson FR, Dente C, Steffes C, Carlin AM. Factors affecting mortality rates in patients with abdominal vascular injuries. J Trauma 2001; 50(6)1020-6.

5. David Jr JK, Gomez GA. Trauma management. In: David BP. Abdominal vascular trauma. 1ed. Boston: Little Brown and Company; 1989. p 306-7.

6. Haimovici H. Transperitoneal exposure of abdominal aorta and iliac arteries. In: Haimovici H. Vascular surgery: principles and techniques. 4ed. Cambridge: Blackwell Science; 1996. p 385-92.

7. Petersen S, Sheldon G, Lim R. Management of portal vein injuries. J Trauma 1979; 19:616-20.

8. Henne-Bruns D, Kremer B. Injuries of the portal vein and vena cava in severe blunt abdominal trauma. Zentralbl Chir 1992; 117(6):343-7.

9. Henne-Bruns D, Kremer B, Lloyd DM, Meyer-Pannwitt U. Injuries of portal vein in patients with blunt abdominal trauma. HPB Surg 1993; 6(3):163-8.

10. Graham DD, May AK, Moore M, Young JS. Management of hepatic artery injury: case report. Am Surg 1997; 63(4): 327-9.

11. Jurkovich GJ, Hoyt DB, Carrico CJ. Pancreatic trauma. Sug Clin North Am 1990; 70(3): 575-93.

12. Machado MAC, Volpe P, Souza Jr AL, Poggetti RS, Branco PD, Birolini D. Lesões traumáticas do pâncreas: análise de 65 casos. Rev Hosp Clin Fac Med S Paulo 1994; 49(6):238-42.

13. Patton Jr JH, Fabian TC. Complex pancreatic injuries. Surg Clin North Am 1996; 76(4):783-95.

14. Goffi FS. Aspectos técnicos das ressecções pancreáticas. In: Colégio Brasileiro de Cirurgiões - Cirurgia do aparelho digestivo. 11ed. São Paulo: Robe Editora; 1991. p143-6.

15. Moore KL. Anatomia orientada para a clínica. 3ed. Rio de Janeiro: Guanabara Koogan; 1994.

16. Testut L, Jacob O. Tratado de anatomia topografica com aplicaciones medicoquirurgicas. 8ed. Barcelona: Salvat Editores;1967. p 135-49.

17. Albu I, Vaida A, Briciu M, Gherman I, Oprea A, Giurgiu T. The portal vein and its main affluents. An anatomic and morphometric study. Morphol Embryol (Bucur) 1982; 28(4):267-72.

18. Falconer CWA, Griffiths E. Anatomy of the blood vessels in region of the pancreas. Br J Surg 1950; 37:334-9. 
19. Correa NA. Clínica cirúrgica. 4ed. São Paulo: Sarvier; 1988. p 559-62.

20. Steinman E, Utiyama EM, Martini AC, Pogetti RS, Birolini D. Lesão traumática da veia porta. Rev Col Bras Cir 1989; $16(5): 234-8$

21. Mantovani M, Meirelles GV, Fraga GP. Abordagem cirúrgica do trauma pancreático e dos descolamentos retroperitoneais.
In: Petroianu A. Terapêutica cirúrgica. 1ed. Rio de Janeiro: Guanabara Koogan; 2001. p 688-96.

22. Patcher HL, Liang HG, Hofstetter SR. Liver and biliary tract trauma. In: Feliciano DV, Moore EE, Mattox KL. Trauma. 3ed. Connecticut: Appleton; 1996. p 487-523.

23. Sheldon GF, Lim RC, Yee ES, et al. Management of injuries to the porta hepatis. Ann Surg 1985; 202(5):539-45.

Mantovani M, Leal RF, Fontelles MJ. Estudo anatômico da veia porta-hepática: abordagem cirúrgica portal transpancreática. Acta Cir Bras [serial online] 2002 Jul-Ago;17(4). Disponível em URL: http://www.scielo.br/acb.

RESUMO - Introdução: No trauma abdominal, o comprometimento dos grandes vasos constitui uma situação de grande complexidade com altos índices de complicações e mortalidade. Nestes pacientes, a lesão da veia porta-hepática tem interesse em razão da dificuldade no diagnóstico e na abordagem cirúrgica. Objetivo: Padronizar o plano de transecção do pâncreas visando o acesso cirúrgico mais seguro para os reparos das lesões da veia porta-hepática. Métodos: Procedeu-se à uma análise quantitativa para caracterizar a relação anatômica da veia porta-hepática e suas tributárias relacionando-as com o pâncreas. Nestes cadáveres, estudou-se as medidas de um triângulo anatômico que tem como base o limite superior da veia mesentérica superior e porção inicial da veia porta; como ápice, um ponto localizado no limite superior da confluência das veias esplênica e mesentérica superior, situado na linha média da veia mesentérica superior. Resultados: A veia porta-hepática é formada a $3.24 \mathrm{~cm}$ da borda interna do arco duodenal numa localização que dista $1.61 \mathrm{~cm}$ e 1.07 das bordas inferior e superior do pâncreas, respectivamente. Conclusão: O presente estudo nos permite concluir que, para se fazer o acesso à origem da veia porta-hepática, em caso de trauma deste vaso, deve-se proceder a secção do colo do pâncreas junto à veia mesentérica superior, pois a confluência entre ela e a veia esplênica ocorre, em média, a $1.07 \mathrm{~cm}$ da borda superior da glândula, e a $1.61 \mathrm{~cm}$ de sua borda inferior.

DESCRITORES - Traumatismos abdominais. Veia porta. Veias hepáticas. Pâncreas.

Conflito de interesse: nenhum Fonte de financiamento: nenhuma

Address for correspondence:

Dr. Mauro José Fontelles

Rua Major Solon, 615/62

13024-907 Campinas - SP

Phone: (19) 294-6850

mikefox@uol.com.br

Data do recebimento: $26 / 01 / 2002$

Data da revisão: 18/02/2002

Data da aprovação: 08/03/2002 